\title{
Doing competence: On the performativity of literacy and numeracy from a post-structural viewpoint
}

\author{
Lisanne Heilmann ${ }^{1}$ (D) \\ Published online: 25 May 2020 \\ (C) The Author(s) 2020
}

\begin{abstract}
International large-scale assessments like the Programme for the International Assessment of Adult Competences (PIAAC) assess literacy and numeracy proficiency as abstract competences, assuming they are cognitive skills and therefore objectively and universally measurable. However, research into how people's lives are affected by notions of literacy and numeracy has shown that both are influenced by social conventions and expectations which are embedded in power relations and ideology. Competences and practices are situated in their social context, and they are products of historical processes which include their construction through the way they are referred to by both experts and the general public. The purpose of this article is to look at literacy and numeracy from a post-structural point of view, questioning the individualised understanding of literacy and numeracy as abstract competences which people simply "have". The author explores the possibility of viewing these basic competences as constructed through how they are actively performed (e.g. when someone engages in reading, writing or calculating for a particular purpose in a particular context) and referred to (e.g. when someone is pronounced "literate" or "competent"). The author points out that being acknowledged and addressed as competent and literate opens up possibilities, just as being viewed as lacking these competences can allow access to (learning) opportunities. Simultaneously and ambivalently, constructed notions of competence both liberate and subordinate individuals. They create power relations and vulnerabilities which often remain unacknowledged.
\end{abstract}

Keywords literacy as social practice $\cdot$ New Literacy Studies · performativity · competence $\cdot$ subject theory $\cdot$ poststructuralism

Lisanne Heilmann

lisanne.heilmann@uni-hamburg.de

1 Department for Lifelong Learning, Faculty of Educational Studies, University of Hamburg, Hamburg, Germany 


\section{Résumé}

Exercer ses compétences : performativité de la littératie et de la numératie d'un point de vue poststructuraliste - Les évaluations internationales à vaste échelle comme le Programme pour l'évaluation internationale des compétences des adultes (PIAACProgramme for the International Assessment of Adult Competencies) évaluent la littératie et la numératie en tant que compétences abstraites, supposant qu'elles sont des compétences cognitives et, par conséquent, objectivement et universellement mesurables. Toutefois, les recherches visant à illustrer la façon dont la littératie et la numératie agissent sur la vie des gens ont montré que ces deux concepts sont influencés par des conventions et attentes sociales intégrées dans des rapports de force et des idéologies. Les compétences et pratiques se situent dans leur contexte social et sont les produits de processus historiques entre autres construits sur la façon dont les experts et le public y font référence. Cet article se propose d'examiner la littératie et la numératie d'un point de vue poststructuraliste, en remettant en question leur conception individualisée en tant que compétences que les gens «possèdent » tout simplement. L'auteure examine la possibilité d'envisager ces compétences de base comme étant construites par la façon dont elles sont activement exercées (p. ex. quand une personne se livre à la lecture, à l'écriture ou au calcul à une fin particulière dans un contexte déterminé) et la façon dont on y fait référence (p. ex. quand on dit d'une personne qu'elle est « alphabète » ou « compétente »). Elle indique que pour cette personne, être reconnue comme compétente et qualifiée d'alphabète lui ouvre des possibilités; de même que considérer qu'elle ne possède pas ces compétences peut lui ouvrir l'accès à certaines possibilités (de s'instruire). Parallèlement, et ce qui est ambivalent, les notions de compétences construites libèrent et subordonnent en même temps les individus, créant des rapports de force et de vulnérabilité qui passent souvent inaperçus.

\section{Introduction}

Language and literacies ${ }^{1}$ and their intricate relationships with power, ideology and discourse affect people and societies. For example, even though the constitutions of many countries worldwide legally stipulate their citizens' right to speak and use their mother tongue, some schools do not in fact recognise this practice because they only teach and test in a language many of their pupils do not understand. But even talking about literacy and theorising on concepts of literacy might already affect and even harm people (see Gee 2008 [1990], p. 5), because this sets standards and norms which are then reproduced in real environments.

In this context, the potential of being discriminated against can take multiple forms. If a person's literacy (i.e. their ability to read, write, calculate and problemsolve) is not accredited by way of certificates or does not fit mainstream society's

\footnotetext{
1 This plural term is used to imply that there is no "single" correct way to read or write, but that there are instead multiple ways to use written language, e.g. in different environments such as the home, shops, workplaces, etc. This includes making sense of printed texts, audiovisual formats, pictures, gestures etc.
} 
expectations, this person might be excluded from the labour market. ${ }^{2}$ Jobs or promotions might not be given to them if their ${ }^{3}$ language or literacy is not the one deemed appropriate or sufficiently educated for the position. ${ }^{4}$ Certain information, for example regarding health-related decisions, might be withheld from people because it is mainly offered in (sophisticated) writing which is inaccessible to them (ERGO and forsa 2012). These are the more apparent exclusionary mechanisms of literacy, numeracy and language. More have been examined in detail for several areas of life and society (e.g. in Yasukawa, Rogers et al. 2018; Grotlüschen and Buddeberg 2020). In this article, I focus on literacy competences (including numerical literacy, i.e. numeracy) and their impact on people's lives as well as the conceptualisation and discussion of literacy as the competence to read, write and understand.

Literacy competences impact people's lives in various forms and ways. International large-scale assessments like the Programme for the International Assessment of Adult Competences (PIAAC) (OECD 2012) test literacy and numeracy as abstract skills and competences. In short, PIAAC defines literacy as

understanding, evaluating, using and engaging with written texts to participate in society, to achieve one's goals, and to develop one's knowledge and potential (OECD 2012, p. 20).

Similarly, numeracy is defined as

the ability to access, use, interpret and communicate mathematical information and ideas, in order to engage in and manage the mathematical demands of a range of situations in adult life (OECD 2012, p. 34).

PIAAC tests the competences of individuals. The test results are compiled into test scores, which do consider social differences, but ultimately portray the scores as individualised achievements. The publication of these internationally comparative test results not only describes a specific part of reality, but also performatively ${ }^{5}$ affects policy decisions or the perception of skills, countries or educational systems (e. g. Gorur 2016, p. 600).

\footnotetext{
${ }^{2}$ On the relationships between the labour market, qualifications and literacy proficiency, see for example Grotlüschen et al. (2016); on the insufficient acknowledgement of literacy practices in conventional measurements, see for example Scribner and Cole (1978) and Barton and Hamilton (2003).

${ }^{3}$ This article uses the words "they", "their", "them" as gender-neutral singular pronouns.

${ }^{4}$ In this context, "educated language" or "language of education" refers to the concept underlying the German term Bildungssprache, a composite noun. There is no exact English equivalent for Bildung; the closest rough translations are education, formation or personal development. Sprache is the German word for language. Bildungssprache, as conceptualised by German philosopher Jürgen Habermas, refers to the use of language as it is taught and valued in mainstream school classrooms. For more information, see Habermas (1978) and Gogolin and Lange (2011).

${ }^{5}$ The academic concept of performativity is generally attributed to John Langshaw Austin, a British philosopher of language (Austin 1962). It refers to language not only being descriptive of the world but also having an effect on the world.
} 
Starting in the 1980s, a strand of research termed the New Literacy Studies $(\mathrm{NLS})^{6}$ increasingly questioned the individualised understanding of literacy as an abstract competence. Researchers like Sylvia Scribner and Michael Cole (1978), Shirley Brice Heath $(1982,1983)$, or Brian Street $(1995,2003)$ brought the effects of power relations into focus, and Harvey J. Graff (2010) or Jean Lave (2004[1991]), for example, drew attention to the historicised nature of literacy and numeracy. Theoretical discourse began to shift towards conceptualising literacy and numeracy as social practices (Barton and Hamilton 2003; Yasukawa, Rogers et al. 2018). ${ }^{7}$

According to James Paul Gee (2008[1990]), in all social practices, there are "tacit theories that empower or disempower people and groups of people" (Gee 2008 [1990], p. 5). One of these tacit theories may be the way in which a specific understanding of literacy (a literacy discourse) influences and affects people. The NLS approach does not offer a theory of identity or of subject formation ${ }^{8}$ but instead offers ideas of how literacy and numeracy shape and form people that play relevant roles in its theorisation.

At the same time, postmodern and especially post-structural theories ${ }^{9}$ have been gaining popularity in the social and educational sciences (Ricken 2019, pp. 96-99). Questions of power relations have taken on an increasingly central role in cultural studies (Moebius 2010, p. 152). Assumptions are questioned and structures are historicised (treated as historical), thereby revealing how earlier assumptions were produced performatively (Moebius 2010, p. 152). Subjects are also produced and therefore ambivalently both liberated and subordinated by the power structures and discourses they are subject to (Foucault 2017 [1976]; Butler 1997a).

The purpose of this article is to look at literacy and numeracy from a post-structural point of view. To do so, I first introduce a number of exemplary post-structural theories and approaches, which I then apply to literacy. In the second section, I outline the central approaches of the NLS to literacy (and numeracy). In the third section, I present the possibility of thinking about literacy with a post-structural approach by looking at how literacy events ${ }^{10}$ continuously reconstruct themselves, how the competence of a person is not measured but created by their performance

\footnotetext{
6 The field of the New Literacy Studies is "something like 'integrated social-cultural-political-historical literacy studies', which names the viewpoint it takes on literacy" (Gee 2008 [1990], p. 150), replacing ."the old 'oral culture-literate culture' contrast" (ibid., p. 67).

7 Social practices are acts which are carried out in a conventional way and derive their meaning from their social context, e.g. describing a love letter as a social practice implies that there is some kind of conventional way of writing a love letter (so it may be recognised as a love letter) and that its meaning and value are (at least partly) formed by this convention.

8 Subject formation is a term used in subject theory. It refers to the ongoing process in which a person (the subject) is constantly (re-)shaped (formed) by the power someone else has over them. (Butler 1997b).

${ }^{9}$ In a nutshell, postmodernism questions established values and truths, arguing they are socially constructed. Post-structuralism contends that the meaning of a term (such as, for example, "literate" and "competent") is unstable, arguing there are always alternative possibilities of explanation and interpretation. From a post-structuralist perspective, however, these unstable and contingent meanings are our only means of thinking of and interacting with the world.

10 A literacy event is an occasion where literacy is practised or performed (e.g. a person reading a newspaper).
} 
in a survey, and at how different literacy discourses may produce both liberated and subordinated subjects.

\section{Performativity and subjection}

Both performativity and subjection have long histories in multiple disciplines and theories. The following paragraphs focus on three theoretical strains. The first is John Langshaw Austin's linguistic philosophy of truth, epitomised in his lecture How to do things with words (Austin 1962), which became one of the seminal texts on the performativity of language and invocation. ${ }^{11}$ The second is Candace West and Don H. Zimmerman's approach of “doing” (West and Zimmerman 1987), which shows how assumedly inherent traits of subjects are performatively produced. Finally, the third is Judith Butler's theory of subjection (Butler 1997a, b), where she radicalises this idea of performative production and shows how invocations are producing and at the same time subordinating subjects.

\section{John Langshaw Austin's linguistic philosophy of truth}

In his lecture entitled How to do things with words, John Langshaw Austin proposed to look at speech not only as something that could entail consequences, but also as an act in which reality is produced. He examined the events in which any kind of speech or utterance occurred. He then described how in and by these "speech events" reality is produced. Sentences like "I hereby marry you" or "I hereby promise" are sentences that evoke immediate changes. Austin extends this, arguing that all speech is performative, since every utterance can be understood as a declaration of intent in any shape or form. He therefore calls them speech acts (Austin 1962).

For a speech act to be performative, he proposed four necessary conditions; ${ }^{12}$ if these are not met, the occasion will be, in Austin's words, unhappy (Austin 1962, 14ff.), in other words, communication will be unsuccessful because the speaker or the circumstances might be wrong, or their speech may even make no sense at all.

(A.1) There must exist an accepted conventional procedure having a certain conventional effect, that procedure to include the uttering of certain words by certain persons in certain circumstances, and further,

\footnotetext{
11 In this academic context, Austin used the term invocation to refer to addressing a person and thereby having a performative effect on that person. In plain English, it means that how people are addressed and what they are addressed as has an impact on what they are seen as and ultimately determines who and what they are, i.e. what they are seen as. For example, addressing a person coming to your door as a postman/-woman automatically includes also addressing them with all the common associations, e.g. regarding their social status.

${ }^{12}$ Two further conditions (labelled $\Gamma$ ) are omitted here. They address the congruence of intention and procedural goal. A speech act can be performative even if these conditions are not met, and they are therefore of less relevance for this article.
} 
(A.2) the particular persons and circumstances in a given case must be appropriate for the invocation of the particular procedure invoked

(B.1) The procedure must be executed by all participants correctly and

(B.2) completely. (Austin 1962, pp. 14-15)

If conditions A.1 and A.2 are not met, the speech act tries to invoke a non-existing or inappropriate procedure. If an existing and appropriate procedure is invoked, the conditions labelled B must be met to achieve a happy execution of the speech act (Austin 1962, p. 17), i.e. achieve successful communication.

\section{Candace West and Don H. Zimmerman's approach of "doing"}

In 1987, Candace West and Don H. Zimmerman co-authored a paper entitled "Doing Gender". This was followed in 1995 by "Doing Difference", a paper West co-authored with Sarah Fenstermaker. Both papers lay out the basic idea that gender, race and class are not natural or mere individual attributes, but rather "an ongoing interactional accomplishment" (West and Fenstermaker 1995, p. 8). They argue that being, for example, a woman is not naturally inherent to a person. Rather, a woman is a person who constantly behaves and presents in ways that their social surroundings can identify as female. For this identification to be successful, the presentation must be close (enough) to the underlying social ideal of what a female person is expected to be and look like, to allow for such a recognition. For a person to be recognised as female, they need to present and behave in such a way - by doing so, they fulfil (albeit often unconsciously) their female role in society (West and Zimmerman 1987).

In sum, a particular attribute does not describe what a person is, but rather what a person does. A subject's performance (and achievement) is attributed (classified) accordingly, and simultaneously recreates the idea behind the attribute. According to Corina Färber (2019), this approach focuses on social roles and practices which invoke the subject while neglecting the subject's self-perception of these invocations.

\section{Judith Butler's theory of subjection}

By contrast, Judith Butler, in line with the work of Michel Foucault (2012 [1971]), argues that subject formation does include perspectives of self-perception (Färber 2019). According to Butler, invocation by discourse and power lies at the fundamental core of a subject's existence; subjects are constituted by discourses; they are its material instance (Butler 1997a, 1997b).

It is not simply that one requires the recognition of the other and that a form of recognition is conferred through subordination, but rather that one is dependent on power for one's very formation, that that formation is impossible without dependency, and that the posture of the adult subject consists precisely in the denial and re-enactment of this dependency (Butler 1997b, p. 9). 
The subject is created in a constant and ambivalent process of discursive formation. Even before a person is born, they are subjected as a child and probably even as girl, boy, healthy, non-healthy, wild, etc. (Butler 1997a, e.g. p. 49). They start school and are addressed as types of learners, as intelligent or as talented, as having potential or as lost cases (Delacour and Chronaki 2019). A subject ambivalently depends on their invocation in order to be constituted as a subject - in order to exist - and it is precisely this construction that subordinates the subject (Butler 1997b, especially pp. 10-18).

\section{Aspects of performativity in the New Literacy Studies (NLS)}

Literacy has often been assumed to be a cognitive skill and therefore objectively and universally measurable (Gee 2015, 35f.). However, multiple studies on literacy and numeracy have shown that both are influenced by and embedded in power relations and ideology (Gee 1989; Street 2003; Yasukawa, Jackson et al. 2018), and in their social and economic contexts (Reder 2016, p. 49). Competences and practices are seen in their social context and as products of historical processes (Lave 2004 [1991], p. 65). In the NLS, voices from multiple disciplines and perspectives merged to form a new, albeit not always unanimous, look at literacy and competences (Gee 2015 , p. 35). Gee (2015) attributes a founding role to several British and US-American linguists and anthropologists like Heath and Street, on whose works I mainly rely in the following section.

\section{Literacy and numeracy as social practice}

The NLS emerged based on the recurring finding that literacy has taken on different forms and meanings throughout history and in different parts of the world. Scribner and Cole (1978) examined the literacies of West African populations, especially the Vai. They found signs that literacy was not dichotomous. Rather, the social contexts in which a specific type of literacy was needed created different "literacy activities", which could be interpreted as expressions of underlying social practices (Scribner and Cole 1978, p. 35).

Shirley Brice Heath (1982, 1983) examined every event in which literacy plays a role and showed how individuals and their position in society are shaped in and through these literacy events; "occasions in which written language is integral to the nature of participants' interactions and their interpretive processes and strategies" (Heath 1982, p. 50).

Children growing up in mainstream communities are expected to develop habits and values which attest to their membership in a "literate society". Children learn certain customs, beliefs, and skills in early enculturation experiences with written materials: the bedtime story is a major literacy event which helps set patterns of behavior that recur repeatedly through the life of mainstream children and adults (Heath 1982, p. 51). 
Acknowledging the situated (context-specific) nature and the multiplicity of literacy practices, more and more research turned away from a "monolithic" (Scribner and Cole 1978, p. 37) understanding of literacy; an understanding in which reading and writing are viewed as abstract and universal capabilities. Brian Street described this prevailing notion of an abstract literacy as an autonomous model of literacy. In this model, literacy is regarded as an independent asset, which exists prior to a single individual's birth and incorporates a clear understanding of a right and wrong form (Street 1993, 2003).

The [autonomous] model, I argue, disguises the cultural and ideological assumptions that underpin it and that can then be presented as though they are neutral and universal (Street 2005, p. 13).

Street goes on to offer an alternative way of understanding literacy using an ideological model.

The alternative, ideological model of literacy offers a more culturally sensitive view of literacy practices as they vary from one context to another. This model starts from different premises than the autonomous model - it posits instead that literacy is a social practice, not simply a technical and neutral skill; that it is always embedded in socially constructed epistemological principles (ibid.).

People's reading and writing practices, their "values, uses and consequences" (Scribner and Cole 1978, p. 37), but also the "conceptions of knowledge, identity and being" (Street 2005, p. 13) are socially constructed. Literacy, therefore, needs to be contested in every aspect. Street notes that literacy practices "are always rooted in a particular world-view and a desire for that view of literacy to dominate and to marginalise others" (Street 2005, p. 13) in reference to Gee's elaborations on ideology and literacy (Gee 2008 [1990]).

\section{Becoming literate}

Questions of identity arise in multiple works of Heath, Street, Gee and others. How does a person become literate? What does it mean for a person to be literate? Heath notes that children are socialised into a community; they internalise customs and values of a group (Heath 1982, p. 51). Jean Lave (2004[1991]) studied social groups which were joined together by common literacy or numeracy practices. Referring to these social groups as communities of practice (Lave and Wenger 2008 [1991]), she observed their influence on the formation of an individual.

Suppose there [are ...] reciprocal, recursive, and transformed partial incorporations of person and world in each other within [...] a complex field of relations between them. This assumption follows if we conceive of learners as whole persons, in activity within the world, and it leads to a distinctive description of learning: Legitimate peripheral participation offers a two-way bridge between the development of knowledgeable skill and identity - the production of persons - and the production and reproduction of communities of practice (Lave 2004 [1991], p. 68). 
This quotation reveals three aspects which are relevant for the argument I present in the next section. First, Lave sees learning as a process of transfer and peripheral participation. In this transfer between individuals and communities, the identity of the individual is developed. Second, we learn that she views this development of ... identity as the production of persons. A person is produced and formed by their legitimate peripheral participation in communities of practice. At the same time, Lave constructs these individuals as whole persons, who are engaged in activity within the world. Person and world are separate entities, which interact with and reproduce each other. In this process they acquire and form new identities (Lave 2004 [1991], pp. 72ff.).

Two decades earlier, James Paul Gee (2008[1990]) had pointed towards the relevance of identity for language to make sense, arguing that it is important "who you are and what you're doing when you say it" (Gee 2008 [1990], p. 151, italics in original). He illustrates this with the following example:

If I enter my neighborhood bar and say to my drinking buddy, as I sit down, "Gotta match?" or "Gimme a match, wouldya?", while placing a napkin on the bar stool to avoid getting my newly pressed designer jeans dirty, I have said the right thing. My language-in-use is just fine. But my saying-doing combination is, nonetheless, all wrong (Gee 2008 [1990], p. 151).

While the given scenario might not necessarily relate to questions of identity, Gee explicitly uses it to demonstrate the idea that who you are is relevant for exercising a literacy practice. He describes the discourses surrounding literacy as "identity kit[s]" (Gee 1991, p. 33).

\section{The performative construction of a literate subject}

The NLS showed that who you are plays an important role for literacy and vice versa. An individual is formed by their interaction with and within literate communities. This can be interpreted as a performative element of literacy events. In this section, I investigate the performative construction of a literate subject using three assumptions or theses.

\section{Thesis I: Literacy events are performative.}

My first thesis is that all literacy events can be seen as performative. This means that in every event in which written text plays a role, this written text and its meaning are reproduced. They are reproduced by the event itself.

As mentioned earlier, Heath defines these literacy events as "occasions in which written language is integral to the nature of participants' interactions and their interpretive processes and strategies" (Heath 1982, p. 50). Heath illustrates this with examples such as reading a bedtime story (or listening to a bedtime story being read), signing an employment contract, or looking through a leaflet on the benefits and risks of flu vaccinations. 
I argue that these events are acts; in a similar way that, according to Austin, speech is an act. I follow his reasoning on the conditions and characteristics of these speech acts. On first sight, speech events and literacy events appear quite different: a written text appears permanent and reviewable, and while a person once wrote it, the text now exists without its author. By contrast, a spoken word is elusive; if not recorded, it is never to be heard again, and its creator is immediately recognisable. However, these differences change once we no longer focus on the written text but on the literacy event surrounding the text. A literacy event involves a type of act which is situated in a particular context, and which contains forms of communication. As such, we can look at a literacy event as a variant of a speech act, which means that it needs to fulfil Austin's conditions to become “happy" (Austin 1962, pp. 14ff.), i.e. successful - and performative.

Signing an employment contract, for example, is an accepted conventional procedure with a certain conventional effect (employment). The signing includes certain written words: the contract itself needs to include a clear phrase stating the intended employment, and the signing is only effective with the correct signatures by the appropriate persons (employer and employee). If any of these conditions are not met, this literacy act does not happen in its intended way. It is misinvoked, i.e. its outcome is unsuccessful. If I tried to offer somebody a contract to work at a company without this company's knowledge or authorisation, the signed contract would be invalid and our literacy event would be "unhappy". Even if we had performed the event following its conventional procedure, I would still not have been the appropriate person. In a similar way, this literacy event would be "unhappy" if one of us decided not to sign the contract or to draw a sunflower instead.

Further unhappy cases of literacy events might occur when reading a bedtime story or looking for health-related information in a leaflet. Just like the speech act, the literacy act also has an accepted conventional procedure that must be invoked accordingly. Let us say that individual A (maybe after happily signing the contract) gets a leaflet from their new employer with the offer to pay for a flu vaccination and further information on its benefits and risks. The conventional procedure would then be that A reads the leaflet, with the desired effect being, conventionally, the understanding of information. For this to succeed, the leaflet needs to include certain words like $f l u$ or vaccination or a few related medical terms. It needs to be in a language that $\mathrm{A}$ can read and understand, and in a font which $\mathrm{A}$ can decipher. In addition to the procedure, the persons and circumstances need to be right. If A stops reading halfway through the leaflet, or if they are distracted and therefore misinterpret or misread the leaflet's information, the literacy act is misexecuted, i.e. has an unsuccessful/unhappy outcome. But if the literacy event is invoked in its conventional form and performed accordingly, this literacy event has the conventional performative effect.

By applying these conditions, we can determine and demonstrate how a literacy event invokes the respective underlying practice or convention. It is no longer just an event in which something occurs, but becomes an act in which literacy is actively performed. It is performative in the sense that within each of these literacy acts, a procedure and its effects are invoked. 


\section{Thesis II: We do not have competences; we perform them.}

As long as competences such as literacy are seen as individual attributes by large sections of society, we can describe them with West, Fenstermaker and Zimmerman's approach (West and Fenstermaker 1995; West and Zimmerman 1987). People perform literacy acts in order to be recognised as having a certain literacy competence. West and Fenstermaker propose their approach as "the best prospect for understanding how [...] 'objective' properties of social life achieve their ongoing status" (West and Fenstermaker 1995, p. 33). They argue that this might give an insight into "how the most fundamental divisions of our society are legitimated and maintained" (West and Fenstermaker 1995, p. 33).

As we have learned from the NLS, for a person to be seen as competent or as part of a certain community of practices, they need to perform these practices appropriately. Maria Clara Keating (2005) describes individuals as "persons in the doing". Following West, Fenstermaker and Zimmerman, the focus can be shifted from ascribing "objective" competences towards a recognition of competences: Individuals accomplish being recognised as literate, numerate or competent, and with every recognition, all related values, social roles and the practice itself are reproduced and strengthened, as is the underlying idea of the corresponding competence. What we refer to as "having a competence" can be described as portraying and performing a certain conformity with an underlying idea of literacy and numeracy competences. Competence becomes a performance that, if close enough to the ideal, leads to an individual being recognised and addressed as a subject with that particular competence. We become competent/literate/numerate by performing and doing competence.

This approach to literacy offers a possibility to think of literacy as situated and performed according to social conventions while including an explanation for supposedly objective competences. However, this approach remains at the level of social practices and acts and is limited in examining the underlying ideas and discourses surrounding competences and their power relations.

\section{Thesis III: Literacy discourses form and subordinate literate subjects.}

Gee describes these underlying competence discourses as "ways of recognizing and getting recognized as certain sorts of whos doing certain sorts of whats" (Gee 2008 [1990], p. 156, italics in original). While Gee's and Foucault's concepts of discourse differ, ${ }^{13}$ both view literacy discourses as something that creates or forms a subject according to a specific idea of competence. In every literacy event, at least one

\footnotetext{
13 The fundamental difference relevant for the framework of this article concerns the focal point of their respective work. Gee's understanding of discourse is focused on social roles and practices in which ideas, norms and values lie, see Gee (2008[1990], p. 161). Whereas Foucault focuses on these ideas, norms and values and sees social practices as materialisation of the subjection by the discourse, Gee's concept of ideology appears to be closer to Foucault's concept of discourse; see Foucault (2012[1971]) and Gee (2008 [1990], p. 4).
} 
version of literacy discourse is performed and reproduced. All individuals involved are invoked and subordinated by that literacy discourse. At the same time, it forms them, allows them and their actions to be intelligible, and allocates a social position according to their recognised competences. Thus, the discourse is reproduced.

A specific orthography, for example, can be seen as a specific literacy discourse. Individuals are subjected to it and the expectation of its correct use. At the same time, it allows them to communicate, to read and write. The orthography can be tested, mistakes quantified and skills levels certified. Being acknowledged as literate and competent might lead to job offers, whereas being invoked as illiterate might be accompanied by social stigma - but also by offers to join literacy courses. Every use of the dominant orthography, every mistake that is noticed, tested or quantified reinforces the orthography discourse and its dominance (see Ernest 2019; Ravn and Skovsmose 2019).

Regarding the employment contract, both employer and employee are subjects of multiple discourses surrounding employment or employment contracts (e.g. that the latter need to be in written form). Both parties are constructed as subjects who are able to read and understand the language, the type and the level of complexity in the language of the contract. The subjection becomes more noticeable if, for example, the employee-to-be found themselves struggling to understand the legal terminology of the contract. It would become (consciously or unconsciously) clear to them that, in the terms of this discourse, they lacked the competence that this literacy event so clearly required from them. The individual is not only subjected to norms and conventions as an employee, but also as a (not sufficiently) literate subject.

Competence discourses and their performative formation of subjects are a necessary condition to allow talking or thinking about competences, or teaching them. The dominant discourses determine which literacy is regarded as valuable. They make the individual intelligible, and allow for "existence and agency" (Butler 1997 b, p. 11). At the same time, these discourses incorporate the "taken for granted and tacit set of 'theories' about what counts as a 'normal' person"; any deviation from this ideal might be reflected in the distribution of "status, worth, and material goods" (Gee 2008 [1990], p. 4). With this approach, a social practice, like reading a newspaper in the morning, and assessed literacy scores, for example in PIAAC, can be described in a common theoretical framework as materialisations of different literacy discourses. They intersect with each other and a multitude of other discourses (on race, gender, class, etc.) and produce social disparity.

\section{Conclusion}

The connection between a post-structural conceptualisation of discourse and subject and NLS's findings on situated literacy practices led to my consideration of the three theses discussed in the previous section. Every occasion that involves literacy prompts the reconstruction of underlying assumptions, norms and values regarding literacy and the participating individuals. Therefore, ideas about literacy and competences are constantly being constructed and reconstructed. Literacy is performed in and through these events; we do not have competences; we are performing them by 
behaving in a way that makes others recognise their ideas of competence in in our actions, and thus in us. A necessary condition for the (successful) performance of these events is that they are and have been subjected to literacy discourses.

If we accept the three assumptions/theses made in this article, we can describe literacy, numeracy and other competences as specific discourses. These discourses are materialised in specific events and practices, where, in turn, the competence discourses are reproduced. The approach presented here shares similarities with the social practices approach. Both reject any ideas of abstract or universal competences and both advocate focusing on social and situated acts. The discursive approach presented in this article allows for the analysis of observable practices as well as quantified measurements in the same theoretical framework. Furthermore, it potentially allows for an analysis of the assessments themselves, as these can be framed as materialisations of a dominant discourse and even as specific power techniques that work to uphold the dominance of that particular discourse.

The same goes for (scientific and non-scientific) talk about literacy. In every instance in which a specific literacy practice is mentioned, the underlying discourse is reproduced; and with it its complex power mechanisms. I argue that as long as societal discourses (in schools, the labour market or in the general population) view competences as being internal and objective, every act of teaching, talking, measuring, judging, etc. will reinforce these competence discourses, no matter how researchers describe them.

I propose that the discourse approach allows us take into account both the situated nature of practices as well as the mainstream ideas of competences and the underlying power mechanisms and resulting vulnerabilities. While power relations do play a vital role in the NLS (e.g. Gee 2008 [1990]; Street 2003), I propose that there is potential in using post-structural conceptualisations of power and embedding them in the NLS framework to enable closer analysis and a better understanding of how power and literacy are related. Just as I can identify somebody as what dominant discourse refers to as a "woman", I can identify a "competent" person by the proximity of their performance to the respective competence discourse. I argue that it is precisely my identification which made the person competent in the first place and at the same time subjected them and myself to the discourse's expectations. In this sense, competence is purely relational and bears no comment on the individual. It merely reflects dominant discourses.

In addition, the intersections of competence discourses with gender, race or class discourses need to be examined more closely. Heeding Gee's admonition that

it is a moral obligation to render one's tacit, taken-for-granted theories overt when they have the potential to hurt people (Gee 2008 [1990], p. 5),

it seems imperative that literacy and numeracy research look further into vulnerabilities that arise specifically through subjection in literacy and numeracy discourses.

On a final note, as long as an attribute derives from an individual themselves, societies tend to view the social conventions and expectations it is associated with "as normal and natural, that is, legitimate ways of organizing social life" (West and Fenstermaker 1995, p. 24). If literacy, numeracy and other basic competences are understood as constructed in discourse, we might utilise this concept to question 
the legitimacy of distributing and allocating goods and privilege according to constructed, performed and subjectivising competences.

\section{Acknowledgments Open Access funding provided by Projekt DEAL.}

Funding This study was funded by Landesforschungsförderung Hamburg.

Open Access This article is licensed under a Creative Commons Attribution 4.0 International License, which permits use, sharing, adaptation, distribution and reproduction in any medium or format, as long as you give appropriate credit to the original author(s) and the source, provide a link to the Creative Commons licence, and indicate if changes were made. The images or other third party material in this article are included in the article's Creative Commons licence, unless indicated otherwise in a credit line to the material. If material is not included in the article's Creative Commons licence and your intended use is not permitted by statutory regulation or exceeds the permitted use, you will need to obtain permission directly from the copyright holder. To view a copy of this licence, visit http://creativecommons.org/licen ses/by/4.0/.

\section{References}

Austin, J. L. (1962). How to do things with words: The William James lectures delivered at Harvard University in 1955. Oxford, UK: Oxford Univ. Press.

Barton, D., \& Hamilton, M. (2003). Literacy practices. In D. Barton, M. Hamilton, \& R. Ivanič (Eds.), Situated literacies: Reading and writing in context (reprint) (pp. 6-14). Literacies series. London: Routledge.

Butler, J. (1990). Gender trouble: Feminism and the subversion of identity. Thinking gender series. New York, NY: Routledge.

Butler, J. (1997a). Excitable speech: A politics of the performative. New York, NY: Routledge.

Butler, J.(1997b). The psychic life of power: Theories in subjection. Stanford, CA: Stanford University Press.

ERGO \& forsa (2012). Verständlichkeit von Informationen: Studienergebnisse 2012 [Intelligibility of information: Study results 2012] forsa. 25878/Q1667 01/12 Fr/Bü. Munich/Berlin: ERGO/forsa Gesellschaft für Sozialforschung und statistische Analysen. Retrieved 3 December 2019 from www. ergo.com/ /media/ERGOcom/PDF/Studien/Verstaendlichkeitsstudie/ERGO-Verstaendlichkeitsst udie-Ergebniss-2012.pdf.

Delacour, L., \& Chronaki, A. (2019). The discursive fabrication of the desired child in early childhood mathematics education in Sweden. Philosophy of Mathematics Education Journal, 35 [online article]. Retrieved 23 April 2020 from http://socialsciences.exeter.ac.uk/education/research/centres/ stem/publications/pmej/pome35/index.html.

Ernest, P. (2019). Privilege, power and performativity: The ethics of mathematics in society and education. Philosophy of Mathematics Education Journal, 35 [online article]. Retrieved 23 April 2020 from http://socialsciences.exeter.ac.uk/education/research/centres/stem/publications/pmej/pome35/ index.html.

Färber, C. (2019). Subjektivierung in der Pädagogik: Das Subjekt zwischen Ent- und Ermächtigung [Subjectification in pedagogy: The subject between empowerment and disempowerment]. In N. Ricken, R. Casale, \& C. Thompson (Eds.), Subjektivierung: Erziehungswissenschaftliche Theorieperspektiven [Subjectification: Educational theory perspectives] (pp. 76-92). Schriftenreihe der DGfEKommission Bildungs- und Erziehungsphilosophie. Weinheim: Beltz Juventa.

Foucault, M.(2012 [1971]). Die Ordnung des Diskurses (erweiterte Ausgabe, 12. Auflage) [The order of discourse (extended edn, 12th printing)]. Fischer Wissenschaft series, vol. 10083. Frankfurt am Main: Fischer.

Foucault, M. (2017 [1976]). Der Wille zum Wissen (21. Auflage) [The will to knowledge (21st edn)]. Sexualität und Wahrheit, Bd. 1 [The history of sexuality, vol. 1] Suhrkamp Taschenbuch Wissenschaft series, vol. 716). Frankfurt am Main: Suhrkamp. 
Gee, J. P. (1989). Literacy, discourse, and linguistics: Introduction. Journal of Education, 171(1), 5-17.

Gee, J. P. (1991). Socio-cultural approaches to literacy (literacies). Annual Review of Applied Linguistics, 12, 31-48. https://doi.org/10.1017/S0267190500002130.

Gee, J.P. (2008 [1990]). Social linguistics and literacies: Ideology in discourses (3rd edn). Critical perspectives on literacy and education series. London: Taylor \& Francis.

Gee, J.P. (2015). The New Literacy Studies. In J. Rowsell \& K. Pahl (Eds), Routledge handbooks. The Routledge handbook of literacy studies (pp. 35-48). London: Routledge.

Gogolin, I., \& Lange, I. (2011). Bildungssprache und Durchgängige Sprachbildung [Language of education and continuous language training]. In S. Fürstenau \& M. Gomolla (Eds.), Migration und schulischer Wandel: Mehrsprachigkeit [Migration and academic change: Multilingualism] (pp. 107-127). Migration und schulischer Wandel series. Wiesbaden: VS Verlag für Sozialwissenschaften/Springer Fachmedien.

Gorur, R. (2016). Seeing like PISA: A cautionary tale about the performativity of international assessments. European Educational Research Journal, 15(5), 598-616. https://doi.org/10.1177/14749 04116658299.

Graff, H. J. (2010). The Literacy myth at thirty. Journal of Social History, 43(3), 635-661.

Grotlüschen, A., Mallows, D., Reder, S., \& Sabatini, J. (2016): Adults with low proficiency in literacy or numeracy. OECD Education Working Papers, 131. Paris: OECD Publishing. https://doi. org/10.1787/5jm0v44bnmnx-en

Grotlüschen, A. \& Buddeberg, K. (Eds) (2020). LEO 2018: Leben mit geringer Literalität [LEO 2018: Living with low literacy]. Bielefeld: wbv.

Habermas, J. (1978). Umgangssprache, Wissenschaftssprache, Bildungssprache [Colloquial language, scientific language, educational language]. Merkur Deutsche Zeitschrift für europäisches Denken, 3(359), 327-342.

Heath, S. B. (1982). What no bedtime story means: Narrative skills at home and school. Language in Society, 11(1), 49-76.

Heath, S.B. (1983). Ways with words. Language, life, and work in communities and classrooms. Cambridge: Cambridge University Press.

Keating, M. C. (2005). The person in the doing: Negotiating the experience of self. In D. Barton \& K. Tusting (Eds.), Beyond communities of practice: Language, power and social context (pp. 105-138). Cambridge: Cambridge University Press.

Lave, J. (2004 [1991]). Situating learning in communities of practice. In L.B. Resnick, J.M. Levine \& S.D. Teasley (Eds), Perspectives on socially shared cognition (pp. 63-82). Washington, DC: American Psychological Association.

Lave, J., \& Wenger, E. (2008 [1991]). Situated learning: Legitimate peripheral participation. Learning in doing. Cambridge and New York: Cambridge University Press.

Lewis, A. E. (2003). Everyday race-making. American Behavioral Scientist, 7(3), 283-305. https://doi. org/10.1177/0002764203256188.

Moebius, S. (2010). Kultur (2., überarbeitete Auflage) [Culture (2nd, revised edn)]. Einsichten series. Bielefeld: transcript Verlag.

OECD (Organisation for Economic Co-operation and Development). (2012). Literacy, numeracy and problem solving in technology-rich environments: Framework for the OECD Survey of Adult Skills. Paris: OECD Publishing. https://doi.org/10.1787/9789264128859-en.

Ravn, O., \& Skovsmose, O. (2019). Connecting humans to equations: A reinterpretation of the philosophy of mathematics. Cham: Springer International Publishing.

Reder, S. (2016). Skill use: Engagement in reading, writing and numeracy practices. In A. Grotlüschen, D. Mallows, S. Reder \& J. Sabatini (2016): Adults with low proficiency in literacy or numeracy (pp. 37-59). OECD Education Working Papers, 131. Paris: OECD Publishing. https://doi. org/10.1787/5jm0v44bnmnx-en.

Ricken, N. (2019). Bildung und Subjektivierung. Bemerkung zum Verhältnis zweier Theorieperspektiven [Education and subjectivisation: A note on the relationship between two theoretical perspectives]. In N. Ricken, R. Casale \& C. Thompson (Eds), Subjektivierung: Erziehungswissenschaftliche Theorieperspektiven [Subjectification: Educational theory perspectives] (pp. 95-118). Schriftenreihe der DGfE-Kommission Bildungs- und Erziehungsphilosophie, vol. 1. Weinheim: Beltz Juventa.

Scribner, S., \& Cole, M. (1978). Unpackaging literacy. Social Science Information, 17(1), 19-40. https:// doi.org/10.1177/053901847801700102. 
Street, B. (1993). Introduction. The New Literacy Studies. In B. Street (Ed.), Cross-cultural approaches to literacy (pp. 1-21). Cambridge studies in oral and literate culture, vol. 23. Cambridge: Cambridge University Press.

Street, B. (1995). Social literacies: Critical approaches to literacy in development, ethnography, and education. Real language series. London: Longman

Street, B. (2003). What's "new" in the New Literacy Studies? Critical approaches to literacy in theory and practice. Current Issues in Comparative Education, 5(2), 77-91.

Street, B.(2005). Understanding and defining literacy. Background paper prepared for the Education for All Global Monitoring Report 2006 Literacy for Life. Retrieved 23 April 2020 from https://unesd oc.unesco.org/ark:/48223/pf0000146186.

West, C., \& Fenstermaker, S. (1995). Doing difference. Gender and Society, 9(1), 8-37. https://doi. org/10.1177/089124395009001002.

West, C., \& Zimmerman, D. H. (1987). Doing gender. Gender and Society, 1(2), 125-151.

Yasukawa, K., Jackson, K., Kane, P., \& Coben, D. (2018a). Mapping the terrain of social practice perspectives of numeracy. In K. Yasukawa, A. Rogers, K. Jackson, \& B. Street (Eds.), Numeracy as social practice: Global and local perspectives (pp. 3-17). New York, NY: Routledge.

Yasukawa, K., Rogers, A., Jackson, K., \& Street, B. (Eds.). (2018b). Numeracy as Social practice: Global and local perspectives. New York, NY: Routledge.

Publisher's Note Springer Nature remains neutral with regard to jurisdictional claims in published maps and institutional affiliations.

Lisanne Heilmann is a researcher at the Department for Lifelong Learning at the University of Hamburg, Germany. Lisanne is member of the research team of the LEO 2018 - living with low literacy survey and project coordinator of the Hamburg Numeracy Project. Their research focuses on questions of social equality and vulnerability in relation to adults' (basic) competencies, employing both quantitative empirical methods as well as post-structural theories. 